extracted muscle could causc only ncgligible tension developments in the presence of ATP and ACh $\left(10^{-4}\right.$ to $\left.10^{-3} \mathrm{~g} / \mathrm{ml}\right)$. In 16 preparations out of 22 preparations, choline $\left(10^{-4} \mathrm{~g} / \mathrm{ml}\right)$ or histamine $\left(10^{-4} \mathrm{~g} / \mathrm{ml}\right)$ induced little tension development with ATP (Fig. 1-f and g). Both drugs did not contract the isolated muscle strips of the dog small intestines even at so high concentrations as $10^{-5} \mathrm{~g} / \mathrm{ml}$. So the activities of drugs tested in this subcellular experiment were very similar to those shown in intact muscle strips of the dog small intestines. The concentrations of drugs were, however, very high compared with the physiological concentration and so simple extrusion of GEDTA-chelatable cations (i.e. Ca ions) from the fraction by competition with high doses of cationic drugs might be supposed. The facts, however, that choline, histamine and atropine could not show any tension development even at high doses may deny the above mechanism. The reproducibility was not sufficient even in these experiments using glycerol extracted skeletal muscle, but investigation with glycerol extracted dog small intestinal smooth muscle showed smaller and slower tension development and it is lacking considerably in reproducibility even when ATP and Ca ions were used. Therefore as a model of contracting protein glyccrol cxtracted skcletal muscle was utilized.

Of course, there are no evidences that the fraction keeps unique organizations of ACh receptors in the cells, but we could reproduce some receptor mechanisms in this contraction systcm consisting of the subcellular fraction $\left(\mathrm{P}_{5}\right)$, ATP and glycerol treated rabbit psoas similar to those found in muscle strips of the small intestine. In addition, the other two fractions which wcrc supposed to contain little ACh receptors from the labelling experiment $(1,2)$ could not produce any tension development with $\Lambda \mathrm{TP}$ and ACh.

It may be probably concludcd from the above results that $C_{a}$ ions can be released from $\mathbf{P}_{5}$ fraction by $\Lambda \mathrm{Ch}$ because the tension development was abolished by adding GEDTA (Fig. 1-b). It is not easy to interprete true pharmacomechanical coupling from our experiments. There are considcrable evidences that, in striated and in smooth muscles, a rise in free intracellular Ca activates contraction $(5,6)$. This activator $\mathrm{Ca}$ may arise from an increased influx of the extracellular ion or from translocation of $\mathrm{Ca}$ bound at the surface membrane or concentrated in an intracellular storage site. Our rcsults are supposed to emphasize the ability of $\mathrm{ACh}$ to translocate $\mathrm{Ca}$ ions into the cytoplasm from Ca binding sitcs in membranes.

\title{
REFERENGES
}

1) Takagi, K., Akao, M. and Takahasht, A.: Life Sci. 4, 2165 (1965); 2) Takagr, K. and 'Takahashi, A.: Binchem. Pharmac. 17, 1609 (1968); 3) EBashi, S.: Archs Biochem. Biophys. 76, 410 (1958); 4) LEE, K.S.: J. Pharmac. exp. Ther. 132, $149(1961)$; 5) Sombyo, A.P. And Somlyo, A.V.: Pharmac. Rev. 20, 197 (1968); 6) Herwitz, L. And Jonver, P.D.: Am. J. Physiol. 218, 12 (1970)

\section{EFFECTS OF METOCLOPRAMIDE ON SERUM AND ERYTHROCYTE CHOLINESTERASES}

\author{
EMILIO MARMO \\ Department of Pharmacology, University of Naples, Naples, Italy \\ Received for publication April 20, 1970
}

Mctoclopramide (MT) produces anti-emetic and anti-arrhythmic activities and, with reference to the dose, a stimulating or depressing activity on the gastro-intestinal muscle and that of urinary bladder, uterus and gall bladdcr. 
$\Lambda$ large number of investigations was carried out with MT on the parasympathetic efferential periphery. According to Boissier et al. (1) MT (20 mg/kg i.v.) slightly increases the hypotensive effect by acetylcholine (ACh). According to Kosaka et al. (2) the piloric hypermotility by MT (0.2 $\mathrm{mg} / \mathrm{kg}$ i.v.) in man is not antagonized by atropine ( $10 \mu \mathrm{g} / \mathrm{kg}$ s.c.) or N-butyl-hyoscine bromide $(0.2 \mathrm{mg} / \mathrm{kg}$ i.v. $)$. According to Katsuki et al. (3) the gastric hypermotility by MT (10 mg i.v.) in man is blocked by atropine $(0.5 \mathrm{mg}$ i.m.). According to Shimamoto et al. (4) MT does not produce in vitro anti-ACh effects on several organs. $\Lambda$ ccording to Coullaud ct al. (5) the stimulating effects by MT on the rabbit colon and ileum are not modified, neither in vivo nor in vitro by atropine or hexamethonium. According to Jacoby et al. (6) the stimulating effects by MT on the gastric and duodenal muscle would be antagonized by benztropine in the non-anesthetized dog and by atropine in the anesthetized $\operatorname{dog} ; \mathrm{MT}(2 \mathrm{mg} / \mathrm{kg}$ i.v. $)$ would not potentiate the effects by ACh on the gastric muscle of the dog. According to Eisner (7) MT in conc. of $10^{-6}-10^{-5}$ potentiates the stimulating cffects by ACh on bands of human stomach, pylorus, duodenum, ileum and colon and partly antagonizes the inhibitory cffcct by atropine to ACh; always according to Eisner (8) the stimulating effects by MT on the gastro-intestinal muscle in man would be antagonized by atropine, therefore the hypothesis is advanced that MT has a common receptor with ACh. According to Hukuhara et al. $(8,9)$ the stimulating effect by MT on the rat duodenum and jejunum is not modified in vitro by a previous treatment with hexamethonium or atropine or nicotinc; always according to Hukuhara et al. $(8,9) \mathrm{MT}$ in high conc. $\left(5 \times 10^{-5}-10^{-4}\right)$ would have ganglioplegic effects. According to Mantegazza et al. (10), on the gastro-intestinal muscle MT produces some peripheral effects on the intramural nervous elements with a non well definable mechanism. According to Beani ct al. (11) and Bianchi et al. (12), on the rabbit colon, MT in conc. of $10^{-6}-10^{-5}$ inhibits some nervous structures which may be stimulated with 5-hydroxytryptamine, appointed to depress the cholinergic exciting influences, and scnsibilizes the muscular effector to $\mathrm{ACh}$ without modifying the release of ACh. According to Marmo (13) and Marmo et al. (14-17), MT does not produce in vitro anti-muscarinic effects on several smooth muscles of different animals; and the stimulating effects by $\mathrm{MT}$ on the gastrointestinal and uterine muscle and that of urinary bladder would prevailingly be due to a direct effect of the smooth muscle. In previous researches (14) we obscrved that MT, already in a dose as high as $100 \mu \mathrm{g} / \mathrm{kg}$ i.v, potentiates in the ancsthetized cat (ethylurethane, $1 \mathrm{~g} / \mathrm{kg}$ i.m.), even if bivagotomized, the hypotensive effect by ACh, leaving unchanged the one by oxotremorine; therefore, we investigated the effects by MT on the serum- and erythrocyte-cholinesterases of the rabbit.

TABLE 1. In vitro effects by metoclopramide (MT) and procainamide (PC) on serum- and erythrocyte-cholinesterases of the rabbit.

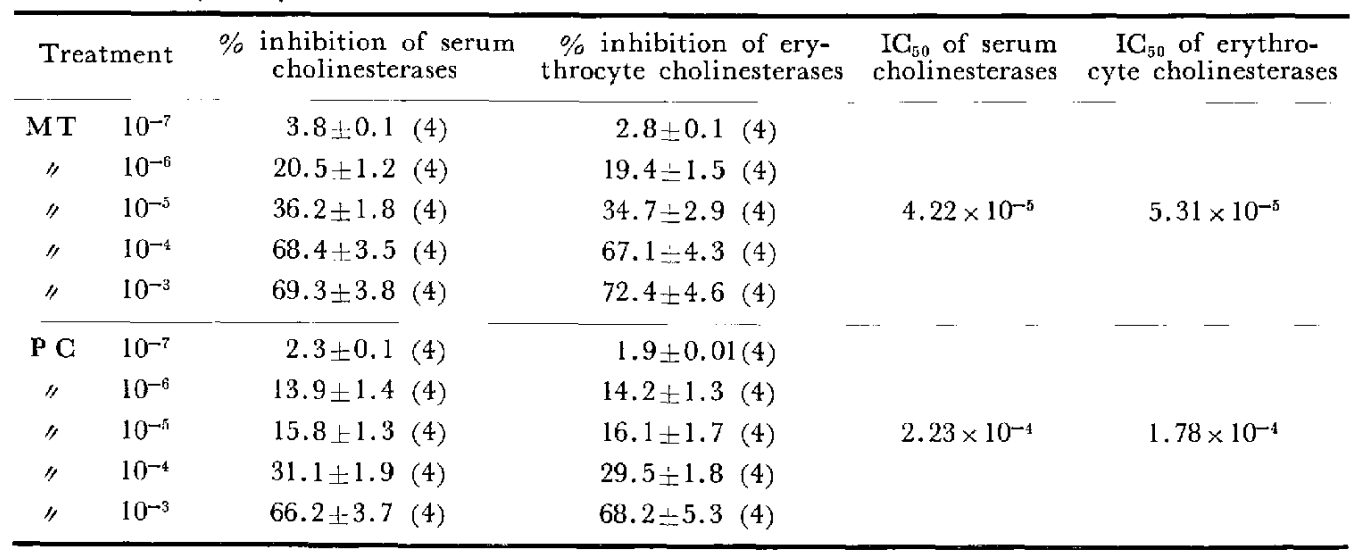

Each value is given as the mean \pm standard error, the number of experiments being given in parentheses. 
The cholinesterases activity was evaluated according to the method of Ellman et al. (18) in the rabbit serum and crytrocytes in the absence or presence of metoclopramide hydrochloride (MT) or procainamide hydrochloride (PC); the incubation lasted 45 minutes; rcadings were made at $25^{\circ} \mathrm{C}$. The determination of $\mathrm{IC}_{501}$ (inhibitory conc. 50) was carried out with the probits method according to Burn et al. (19). In a second group of researches, the hypotensive effects by $\mathrm{ACh}(10-100 \mu \mathrm{g})$, incubated for 30 minutes at $37^{\circ} \mathrm{C}$ with $0.2 \mathrm{ml}$ of rabbit serum added to $50 \mu \mathrm{g}$ of $\mathrm{MT}, \mathrm{PC}$, procaine hydrochloride (P) or prostigmine sulfate (PR), was investigated in cats $(\hat{\delta}, 2.500-2.600 \mathrm{~g})$ ancsthetized with ethylurethanc ( $1 \mathrm{~g} / \mathrm{kg}$ i.m.).
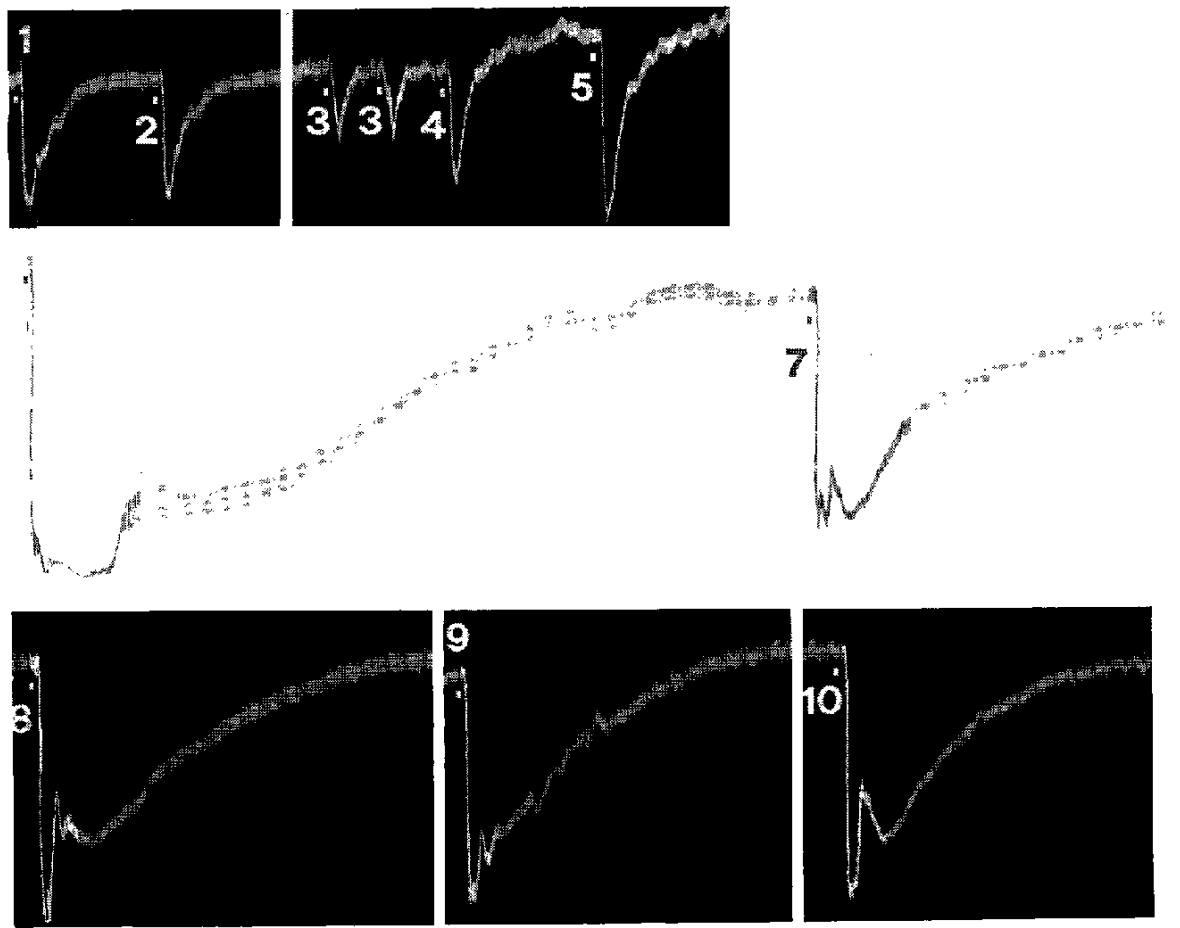

Fig. 1. Cat $\uparrow, 2.5 \mathrm{~kg}$. Carotid artery pressure. $1-2=\mathrm{ACh}(0.25 \% \mathrm{~g}$ i.v.) ; $3=$ rabbit serum $(0.2$

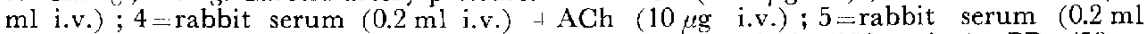
i.v.) - ACh (100 $\mu$ g i.v.) ; $6=$ rabbit serum (0.2 ml i.v.) + ACh (100 $\mu \mathrm{g}$ i.v.) $+\mathrm{PR}$ (50 $\mu \mathrm{g}$ i.v.) ; 7 -rabbit serum $(0.2 \mathrm{ml}$ i.v. $)+$ ACh (10 $\mu \mathrm{g} \mathrm{i.v.})+\mathrm{MT}(50 \mu \mathrm{g} \mathrm{i.v.}) ; 8=$ rabbit serum $(0.2 \mathrm{ml}$ i.v. $)+$ ACh $(100 \mu \mathrm{g} \mathrm{i.v.})+\mathrm{MT}(50 \mu \mathrm{g}$ i.v. $) ; 9=$ rabbit serum $(0.2 \mathrm{ml}$ i.v. $)-\mathrm{ACh}$ (100 $t \mathrm{~g}$ i.v.) $-\mathbf{P C}$ (50 $\mu \mathrm{g}$ i.v.) ; $10=$ rabbit serum $(0.2 \mathrm{ml}$ i.v. $)-\mathrm{ACh}(100 \mu \mathrm{g}$ i.v. $)-\mathrm{P}(50$ $\mu \mathrm{g}$ i.v.). $50 \mu \mathrm{g}$ i.v. of $\mathrm{PR}$ or $\mathrm{MT}$ or $\mathrm{PC}$ or $\mathrm{P}+0.2 \mathrm{ml}$ of rabbit serum don' $\mathrm{t}$ modify the slight hypotensive effect by $0.2 \mathrm{ml}$ i.v. of rabbit scrum.

Metoclopramide produces an anti-cholinesterasic effect as documented by the investigations carricd out on the serum- and erythrocyte-cholinesterases of the rabbit (Table 1) and by the ones carried out while studying the hypotensive effect by ACh incubatc in rabbit serum in the presence or not of MT (Fig. 1); the anti-cholinesterasic effect by MT resulted to be more intensive of that by procainamide or procaine, but less intensive by that of prostigmine (Table 1 and l'ig. 1). We appropriate to cmphasize that the potentiating effects of the responses by ACin, observed by some authors, must be interpreted not as an activation of the muscarinic receptor by MT, but in the sense found by us in the present work (namely, inhibition of the cholinestcrascs). However, this docs not exclude that MT may also inhibit the nervous structures appointed to depress the cholinergic exciting influences [Beani et al. (11), Bianchi et al. (12)].

Acknowledgements: We are greateful to Biagio Ungaro and Lucio Giordano for technical assistence and to Lepetit SpA of Milano for metoclopramide. 


\title{
- REFERENCES
}

1) Borsiter, J.R., Simon, P., Lwoff, J.-M. And Fichelle-Pagny, J.: C.r. Soc. Biol., Paris 158, 1859 (1964);

2) Kosaka, A., Kiyoo, T. and Kinara, T.: Abstr. Comun. Jap. Symposium on Therapy with New Drugs, November, Nagoya (1965); 3) Katsukt, S. AND CoLL.: Abstr. Comun. Jap. Symposium on Therapy with New Drugs, November, Nagoya (1965); 4) Shimamoto, K. ANd Cols: Abstr. Comun. Jap. Symposium on Therapy with Nere Drugs, November, Nagoya (1965); 5) Coullaud, D. And Leveque, J.: Path. Biol. 14, 963 (1966); 6) Jacoby, H.1. AND Brodie, D.A.: Gastroenterology 52, 676 (1967); 7) EisNer, M.: Br. Med. J. 4, 679 (1968); 8) Hukuhara, T., Nakayama, S., Fukuda, H., Sinna, H. and Neya, T.: Jap. J. Smooth Muscle Res. 2, 15 (1966); 9) Hukuhaka, T., Nakayama, S., Fukuda, H. and Neya, T.: Jap. J. Smooth Muscle Res. 2, 22 (1966); 10) Mantegazza, P. and Kabir Naimzada, N.: Abstr. Comun. Simposio sulla Metoclopramide, 9-10 March, Milano, p. 34 (1968); 1I) Beant, L., Buanchi, Gi. and Grema, A.: Abstr. Comun. IV Int. Congr. Pharmacol. 14 -18 July, Basel, p. 232 (1969); 12) Bianchi, Ch., Beani, L. And CRema, A.: Abstr. Comun. XV Congr. Soc. It. Farmacologia 2-3 September, Milano, p. 16 (1969); 13) Marmo, E.: Abstr. Comun. Zsad Polskiego Towarzystwa Farmakologicznego, 3-5 October, Warszawa (1969); 14) Marmo, E., Di Giacomo, S. and Imperatore, A.: Clin. Terap. 51, 509 (1966); 15) Marmo, E., Di Mezza, F., Imperatore, A. and Di Gracomo, S.: Gazz. Int. med. Chir. 74, 1459 (1969); 16) Marmo, E., Magliulo, S. and Di Giacomo, S.: Il Farmaco (Ed. prat.) 24, 342 (1969); 17) Marmo, E., Di MezzA, F., Imperatore, A. and Di Giacomo, S.: Arzneim. Forsch. 20, 18 (1970); 18) Ellman, G.L., Courtney, K.D., Andres, V. Jr. And Featherstone, R.M.: Biochem. Pharmac. 7, 88 (1961); 19) Burn, J.H., Finney, D.J. And Goodwin, L.G.: Biological Standardization II Ed., Oxford Med. Press, Oxford (1952)

\section{EFFECT OF LITHIUM SUBSTITUTION FOR SODIUM ON OXYGEN CONSUMPTION OF GUINEA PIG TAENIA COLI IN HIGH K MEDIUM}

\author{
YUKIO SAITO, YUTAKA SAKAI \\ Medical Laboratory for Pharmacology, Central Research Laboratories, Sankyo Co. Ltd., Shinagawa-ku, Tokyo \\ MIYOSHI IKEDA AND NORIMOTO URAKAWA \\ Department of Veterinary Pharmacology, Faculty of Agriculture, University of Tokyo, Bunkyo-ku, Tokyo \\ Received for publication April 23, 1970
}

It was reported that high potassium solution (isotonic, $40 \mathrm{~mm}$ ) induced a tension development in guinca pig taenia coli accompanied by an incrcasc in oxygen consumption (1). Intracellular Ca space increased in high $\mathrm{K}$ medium as well as cellular $\mathrm{Ca}$ fraction which did not exchange within 4 minutes. The latter is referred to "tightly bound fraction (TBF)" (2). By addition of ouabain $\left(2.5 \times 10^{-8} \mathrm{M}\right)$ to high $\mathrm{K}$ medium the increased oxygen consumption was maintained, although the developed tension was almost abolished, and both changes were dependent on external calcium (3). Moreover, the elevated intracellular $\mathrm{Ca}$ space was maintained by addition of ouabain, while the increased TBF returned to the control level in the high $\mathrm{K}$ medium (2).

When lithium was substituted for sodium at a level above $50 \mathrm{~mm}$ in high $\mathrm{K}$ (hypertonic, $40 \mathrm{~mm}$ ) medium, the developed tension of the musclc gradually decreased to the original level $(4,5)$. In the present

畄藤 友紀雄・酒井 豊・沏田 三義・浦川 紀元 